\title{
Sturge-Weber Syndrome: An Extensive Cutaneous Presentation
}

\section{Síndrome de Sturge-Weber: Uma Apresentação Cutânea Extensa}

\author{
Regina CALDAS $\square^{1}$, Maria GUIMARÃES ${ }^{1}$, Olga FERREIRA ${ }^{1}$ \\ Acta Med Port 2021 May;34(5):387-387 - https://doi.org/10.20344/amp.12671
}

Keywords: Glaucoma; Neurocutaneous Syndromes; Port-Wine Stain; Sturge-Weber Syndrome

Palavras-chave: Glaucoma; Mancha Vinho do Porto; Síndrome de Sturge-Weber; Síndromes Neurocutâneas

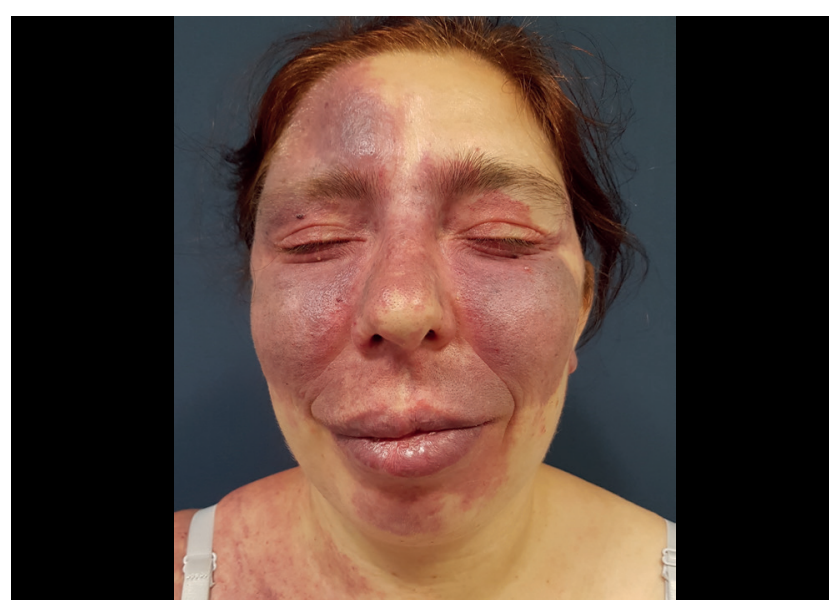

Figure 1 - Port-wine stain covering the right forehead, and the bilateral eyelids, maxillary region and chin

A 40-year-old woman presented with a congenital and generalized port-wine stain. Her medical history was relevant for bilateral glaucoma and seizures of infancy. The physical examination revealed multiple purple to red patches, with irregular, well-defined borders, spreading bilaterally from the face (Fig. 1) to the trunk, right upper limb (Fig. 2) and thighs, without body asymmetries. The magnetic resonance imaging showed slight atrophy of the temporo-occipital right lobe, leptomeningeal enhancement and hypertrophy of the choroid plexus. The clinical and imaging findings supported the diagnosis of Sturge-Weber syndrome.

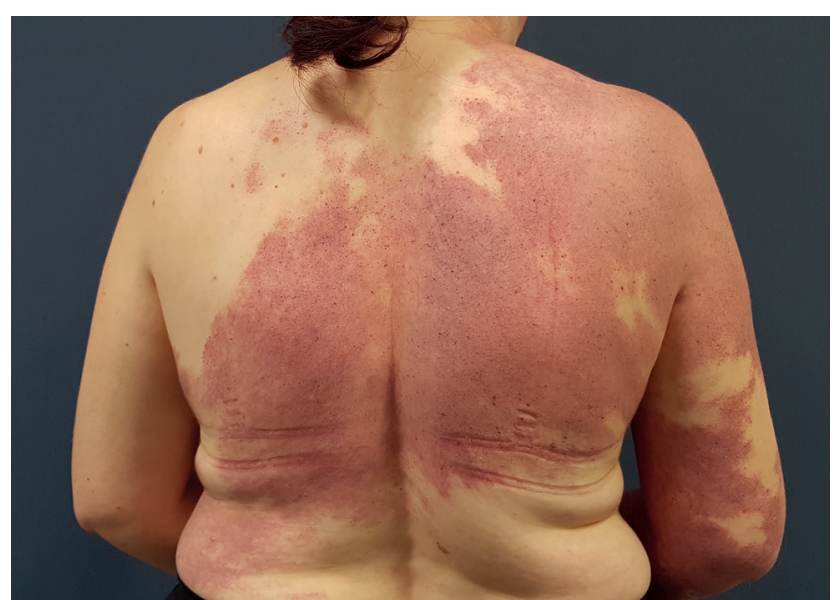

Figure 2 - Port-wine stain covering the posterior trunk and the right upper limb

The patient was referred for pulsed dye laser and maintained multidisciplinary follow-up.

Sturge-Weber syndrome is caused by a somatic mosaic mutation in the GNAQ gene, which induces malformations in the cephalic embryonic vasculature. It is characterized by a facial port-wine stain, often unilateral and rarely extra-facial, leptomeningeal angiomatosis and glaucoma. ${ }^{1,2}$ Skin involvement significantly affects the quality of life of patients. ${ }^{3}$ Nevertheless, neurological and ocular complications are the main prognostic determinants. ${ }^{4}$

PROTECTION OF HUMANS AND ANIMALS: The authors declare that the procedures were followed according to the regulations established by the Clinical Research and Ethics Committee and to the Helsinki Declaration of the World Medical Association updated in 2013. DATA CONFIDENTIALITY: The authors declare having followed the protocols in use at their working center regarding patients' data publication. INFORMED cONSENT: Obtained. CONFLICTS OF INTEREST: All authors report no conflict of interest. FUNDING SOURCES: This research received no specific grant from any funding agency in the public, commercial, or not-for-profit sectors.

\section{REFERENCES}

1. Higueros E, Roe E, Granell E, Baselga E. Sturge-Weber syndrome: a review. Actas Dermosifiliogr. 2017;108:407-17.

2. Mantelli F, Bruscolini A, La Cava M, Abdolrahimzadeh S, Lambiase A. Ocular manifestations of Sturge-Weber syndrome: pathogenesis, diagnosis, and management. Clin Ophthalmol. 2016;10:871-8.

3. Hagen SL, Grey KR, Korta DZ, Kelly KM. Quality of life in adults with facial port-wine stains. J Am Acad Dermatol. 2017;76:695-702.

4. Jagtap S, Srinivas G, Harsha KJ, Radhakrishnan N, Radhakrishnan A. Sturge-Weber syndrome: clinical spectrum, disease course, and outcome of 30 patients. J Child Neurol. 2013;28:725-31.

\footnotetext{
1. Department of Dermatology and Venereology. Hospital de Braga. Braga. Portugal.

$\triangle$ Autor correspondente: Regina Caldas. regina.mimed@gmail.com

Recebido: 09 de agosto de 2019 - Aceite: 26 de dezembro de 2019 - Online issue published: 03 de maio de 2021

Copyright $\odot$ Ordem dos Médicos 2021
} 